\title{
On-line Collaborative Learning for In-service Teacher Education
}

\author{
Ana Cristina B. Salomão \\ São Paulo State University (UNESP), São José do Rio Preto, Brazil \\ E-mail: anacbsalomao@yahoo.com.br
}

\begin{abstract}
This article brings some of the results of a study that analyzes a hybrid course for in-service teachers in the Project Teletandem Brazil: foreign languages for all. In this project, Brazilian teachers of Spanish as a foreign language took part in a blended tandem learning course, communicating via videoconferencing with Uruguayan teachers of Portuguese as a foreign language. The aim of the study was to verify Brazilian teachers' concepts and beliefs concerning language and culture and how the teletandem interactions affected them. After the interactions, teachers' views of culture seemed to also incorporate aspects of culture as an interpersonal process, instead of the factual and static view which was previously predominant. Therefore teacher education programs must consider the possibility of conjugating theory and reflective practice through the use of videoconference tools in order to allow teachers to experience culture rather learn facts about it.
\end{abstract}

Index Terms-communication technology, language teaching, teletandem, culture, teacher education

\section{INTRODUCTION}

In general, studies related to intercultural communication have investigated linguistic and cultural aspects of a determined group of people in order to avoid misunderstandings caused by little or no knowledge of the foreign culture. However, modern definitions of culture and intercultural competence include many more considerations. These considerations include the social, economic and political aspects of the relations among different individuals in a globalized world where longer and longer distances are bridged by technology.

According to Kumaravadivelu [1], there are three strands of thought in sociology that debate the phenomenon of globalization and its relation to culture. The first believes in a cultural homogenization to come, with the North American culture as the dominant center. The second sees a possible cultural heterogenization, with the strengthening of local cultures and religious identities as an answer to the 'threat' of globalization. The third conceives a tension between cultural homogenization and heterogenization.

We believe that the current socioeconomic scenario, after the global crisis which brought reflexes to almost every country in the world but mainly the USA, also influences the nature of globalization, with a possible decline of American imperialism. Our view here is very much the same as the third perspective cited above in relation to the existence of tension between cultural homogenization and heterogenization in our contemporary world. The so-called global village does not denote intensified sociability, but what Tomlinson, cited by Kumaravadivelu [1], calls 'imposed proximity'. In other words, globalization and technological advances have contributed space, time and frontier contractions, but not the expansion of common harmony and shared values among the peoples of the world.

Accordingly, intercultural communication is enhanced by the use of new technologies and brings a significant change to the way we understand the relationship between language, culture and society. For the area of Applied Linguistics, in this scenario, an important task arises: that of significantly investigating the impact of the current “cultural globalization" led by technology on language teaching and teacher education. For computing, this tends to raise issues on the possibilities and the uses that are being made of the new communication tools and how they might transform human relations.

In this article, we discuss some of the results of a research project which aims at investigating the conceptions of culture of in-service teachers, including their beliefs about the language-culture they teach. The study will also consider the effectiveness of a hybrid (blended) in-service teacher education course which takes account of these aspects in both its' theory and practice. The course makes use of a virtual learning environment and videoconferencing. This project is part of the Thematic Project "Teletandem Brazil: foreign languages for all”, a research project from UNESP - São Paulo State University - Department of Education (UNESPAssis), and the Graduate Program in Language Studies (UNESP - São José do Rio Preto), Brazil [2,3].

\section{ON-LINE COLLABORATIVE LEARNING}

Teletandem is a collaborative learning model based on tandem learning which makes use of instant communication tools, including MSN, Skype, ooVoo, etc., to put people in contact so as to learn and teach foreign languages collaboratively. Each person in the partnership teaches his or her own language (or language in which he or she is proficient in) to the other.

In this way, we can say that foreign language learning in-tandem involves pairs of (native or competent) speakers whose aim is to learn each other's language by means of bilingual conversation sessions [2,3]. It is still 
not widespread in Brazil, but it is growing rapidly due to the convergence and spread of technological tools which makes this kind of communication more accessible.

Within an autonomous, reciprocal and collaborative learning context, each partner becomes both a learner of the foreign language and a tutor of his/her mother tongue (or language in which he/she feels proficient). By making use of videoconferencing and of instant messaging, the Teletandem partners have an on-line tandem session which usually takes two hours a week (one for each language). In the session they talk about a topic (which can be previously chosen), exchanging cultural information about their countries and giving each other feedback on language use. They also reflect about their own learning focusing upon content, culture, form, lexicon and on the processes of Teletandem interactions.

Teletandem processes are carried out on bases of commonly agreed and shared principles of reciprocity and autonomy between the participants [2,3]. They are autonomous in their learning but they can resort to a teacher's professional mediation if they wish.

Intertwined with language learning in this collaborative model is the learning/teaching of culture. In the first years of the project Teletandem Brazil, it was mostly undergraduate students who participated as Teletandem partners with undergraduate students from a number of different countries whose native languages were Spanish, French, English or Italian. In 2008, a hybrid course (partly on campus/ partly web-based) was offered by the project Teletandem for in-service Brazilian teachers of Spanish as a foreign language from public schools in Brazil, in which cultural aspects were addressed theoretically and practically.

There were eight Brazilian teachers, whose experience of teaching Spanish as a foreign language ranged from 6 to 20 years, who made regular Teletandem sessions (from May to September of 2009) with Uruguayan and Argentinean teachers of Portuguese as a foreign language through synchronous instant messaging and videoconferencing. They were enrolled in a teacher education course in which they had 4 classes (4 hours each) on campus with Brazilian professors and educators from a renowned university in the state of São Paulo. They also interacted through activities, forums and chats in the virtual environment of the course hosted at Teleduc (a virtual learning environment for distance education created in Brazil in which courses are offered on the Internet). The topics addressed were the principles of tandem and Teletandem learning, how to use the Internet tools necessary for this kind of virtual communication, some research results on Teletandem, autonomy, evaluation and self-evaluation, culture, correction and feedback. Figure 1 illustrates the participants' relations within the course:

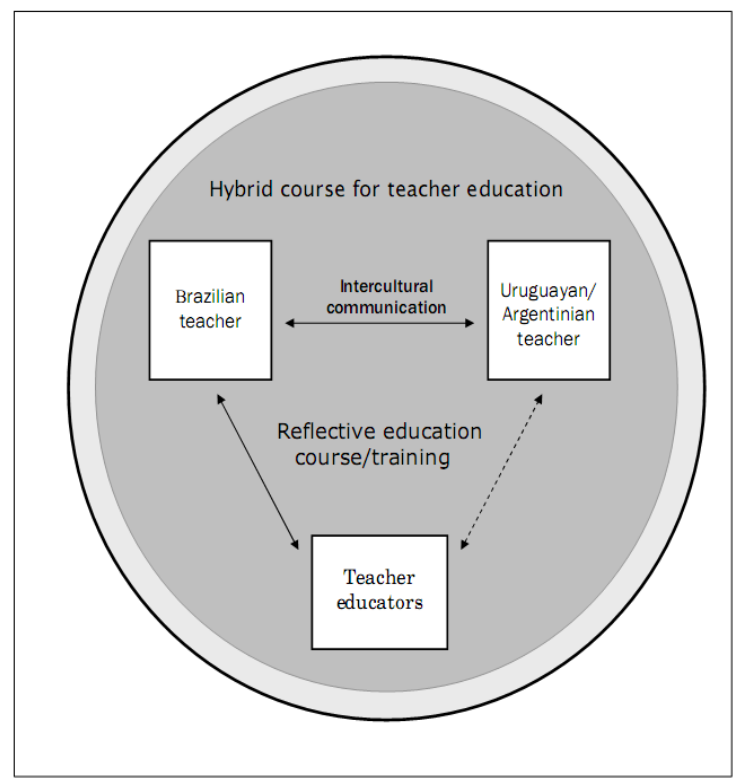

Figure 1: course environment and participants’ relations

The representation in Figure 1 shows that Brazilian teachers made regular teletandem sessions with Uruguayan and Argentinean teachers exchanging cultural information and were supervised by the teacher educators. The Uruguayan and Argentinean teachers appear in the figure connected to the teacher educators by a dotted arrow because they had previously been introduced to Teletandem in a course given by the Teletandem group coordinator in Uruguay (December 2007). They were also enrolled in the Teleduc environment and could take part in the activities proposed if they wished, but this was not mandatory for them.

During the period of the teletandem interactions, the Brazilian teachers were enrolled in an on-line course, entitled "Teacher education for teaching/learning foreign languages in tandem”, within the Teleduc learning environment (Figure 2), where they wrote portfolios on their learning, took part in forums and chats and were supervised by the teacher educators.

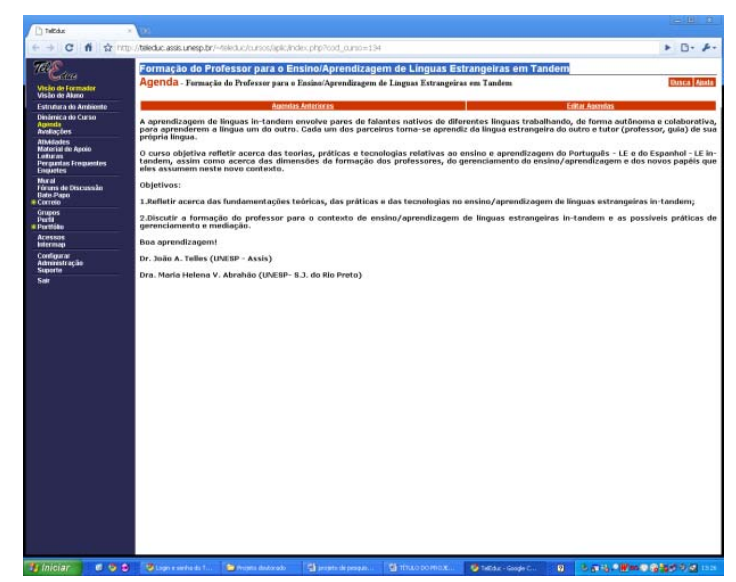

Figure 2: Virtual learning environment of the course in the Internet (Teleduc) 
The data collection involved methods of qualitative studies with an ethnographic basis, such as the intense and long term participation of the researcher in the studied context. The collection involved a careful register of all facts and events, by means of a number of different instruments (autobiographies, questionnaires, interviews, the recording of the classes and Teletandem sessions) and was followed by an analytical reflection over the material gathered $[4,5,6,7]$.

The data were analyzed though an interpretative approach, by reconstituting the participants' views of the events and interaction during the course. The data were firstly analyzed separately, by means of categorization of teachers' expressed beliefs and concepts, and then they were triangulated in order to equate the multiple views and validate the findings [8].

\section{RESUlTS AND Discussion}

In our research, we aimed to discuss the role of the cultural component in current linguistic education and inservice teachers' concepts and beliefs expressed or inferred during the Teletandem interactions and in the blended course they were participating in. Our definition of beliefs here shall be understood, based on Pajares [9] and Barcelos [10], as conceptions, assumptions and knowledge that teachers have in relation to their object of study, which are formed and reformed during their lives, based on individual and collective experiences, and through which they value and interpret the world around them. It is important to highlight that these beliefs are socially constructed and influenced by social, cultural, historical, economic, political and even aesthetic aspects concerning the individual's micro and macrocontexts of interaction in society.

Through the analysis of the teachers' comments and answers to activities related to the topic of culture, it was inferred that most of them see culture as facts about a certain group of people. This view is commonly referred in the literature as culture as civilization, that is, Culture with the capital " $C$ " (History and social institutions) or culture (everyday customs, traditions and practices) [11]. This implies a more static view of culture, seen as a block of information about "the other" that must be presented (prescribed) to the learner in order to enable him/her to avoid misunderstandings.

This seemed to be the dominant view of culture, whereas a more contemporary and dynamic view of 'culture seen as an interpersonal process' which resides not on the concept of culture as a block of national characteristics, but of a variety of factors related to age, genre, regional origin, ethnic background and social class [12] began to be expressed after the Teletandem interactions. The course and teletandem practice seemed to be effective in deconstructing the static view of culture presented by the teachers once they were able to go from theory to practice, through the interaction with a foreign partner.

One very interesting comment from one of the teachers was: "I was in Montevideo (the capital of Uruguay) in 2006 and I was able to perceive the history, customs, and habits of Uruguayans, but with my Teletandem Uruguayan partner culture seems much richer". This comment seemed puzzling at first, as it implied that when she was in Uruguay she did not get to know the culture as well as when she was interacting from her own home in Brazil through the computer with an Uruguayan. This raises issues relating to the power of virtual presence enabled by videoconferencing interactions. The explanation for her sense of getting to know her partner's culture better through the Teletandem interactions than when she was actually traveling in Uruguay may lie on the kind of involvement one has with culture when visiting a country, which is usually that of an observer tourist. Whereas she had probably observed the country and visited famous touristic spots with the help of a professional guide, during the Teletandem sessions her "guide" was her Uruguayan partner, who did not have an established itinerary and allowed her to get the feel of what her daily life was like. Sessions were usually interrupted by members of the family and friends, who had small participations in the interaction, making them spontaneous and lifelike. Technology here seems to have enabled an exchange of information that made culture be seen as a dynamic construction between and among people, consisting of the values, meanings and beliefs that are created in social circumstances [13] once they were experiencing each other's daily lives as if they were inside each other's homes.

Concerning the teaching of culture in the classroom, the teachers appeared to have an understanding of the importance of competence to deal with the foreign culture, but this was mostly from a perspective that one needs to adapt and accept behaviors and attitudes of the foreign language speakers. However, the modern conceptualization of intercultural competence in a foreign language, which is needed to attain communicative competence, "is not how to adapt to any one of the foreign cultures present and forget about his/her own cultural identity” [14]. Instead, many authors and researchers $[12,14,15,16]$ now agree that in an intercultural situation one will have to negotiate, by means of implicit or explicit cues, a situationally adequate system of (inter)cultural standards and linguistic and pragmatic rules of interaction.

That view of the necessity of cultural adaptation presented by the teachers in the beginning of the course appeared to be unchanged by the end of it. But it is difficult to be precise about how future changes might come about after this experience given a teacher's constant cognitive and behavioral change during his/her career (which might be affected by a number of factors besides refresher courses). Borg [17] claims that we are now just starting to understand the complexity of interactions between teachers' cognitions and situational factors both inside and outside the classroom, and in the wider institutional and social context.

Another aspect that must be discussed concerning the teaching of culture is: how can cultural variety be dealt with? Communication technologies have an important role in the enabling access to different peoples and 
cultures by bridging long distances in a multimodal and multisemiotic fashion and intertwining verbal and nonverbal communication. In our research, an interesting aspect arose in the teachers' debates concerning the fact that Spanish is spoken by many different speakers from different nationalities. Although it is spoken in a number of countries in Latin America, which are close to Brazil, most teachers reported a preference for the form as spoken in Spain.

The analysis showed that this was due to a number of factors. One of the most influential is related to these teachers' experiences during their undergraduate courses at university, which was heavily influenced by standards of Spanish from Spain. This might be due to reminiscences of the cultural legacies of colonialism and the strong influence of the Cervantes Institute all over the world. Another factor to be considered is that most of the teachers in this research graduated in language teaching at the university during the 1980's, a time when language teaching in Brazil was still heavily influenced by audiolingualism and foreign models.

Textbooks used in classroom can also account for the teachers' static views, both when they were undergraduate students and during their careers. The way culture was presented to them probably influenced their choices as teachers, with language teaching textbooks usually showing cultural facts based on material production (arts, literature, social institutions and artifacts) and most of these materials come from Spain. We should look at these kinds of materials more critically if we want to provide our students with a linguistic education that considers the existence of cultural diversity positively, and poses the task of comparing similarities and differences not for valuing as good or bad, but for opening a space for dialogue between the target culture and the students' own culture. Thus bringing about intellectual, socio-affective, moral and aesthetic enhancement.

Another factor that could account for these teachers' preference of Spanish from Spain is family influence. Some of the teachers are Spanish descendants and they claimed that this was one of the reasons why they wanted to become teachers of this language, and thus they prefer to maintain their cultural heritage. Only one teacher claimed he preferred Argentinean Spanish, while most of the others said that, in general, they did not know or did not like South American versions of Spanish. Most of the teachers claimed they did not know anything about Uruguay and its culture before the interactions started, despite this country's geographic proximity with Brazil (it borders the south of Brazil). Some of them reported that they were surprised to notice that there was a big resemblance between Brazilian and Uruguayan culture.

It can be said that the social, political and economic status of the different varieties of Spanish could also be seen as an important factor for teachers' choice. Spain is considered a developed country, whereas many of the Spanish speaking South American countries are excolonies and considered as developing countries. Even stereotypes and generalizations of certain groups and cultures in South America appear to play a major role in the choice. For instance, no teachers referred to the Spanish spoken in Paraguay, a neighboring country which is very close to Brazil, but is known as a place where people go to buy fake products, which seems to be a strong reason for prejudice. These kinds of generalizations and stereotypes seem to have a strong impact on the way these teachers valued certain cultures. The impact of the interactions seems to be that of opening a window of opportunity for them to be in contact with a different variety of Spanish, mediated by multimedia technology, that allows them not only to read and get facts about that culture but also to interact through audio and video at distance and share experiences with their foreign partners.

Our study allows us to conclude that the Teletandem interactions between the Brazilian teachers and ones from different nationalities gave them an opportunity to go beyond the predominant view of culture as generalizations and facts about the other. This perception, which had probably been influenced by their experiences as learners, their experiences in teacher education and during their careers as teachers, involves an ability or necessity that we appear to have for characterization and generalization, probably reminiscent of rationalist epistemology. The technology mediated interactions added to the reflections they made in the platform of the blended course, both in the forums and chats, appeared to have enabled them to think of culture from a practical perspective. At the same time they were able to reflect on the meanings of their experience in the intercultural contact.

\section{CONCLUSION}

The data presented in this paper show that the teachers in the study mostly presented static views of culture, related to the material production of certain peoples, which could be traced to their experiences in life and during teacher education. This static view was modified by the interactions of Teletandem sessions, where they could reflect about their own culture as compared to their partners' from another nationality, which also enabled them to express a view of culture as a dynamic construction between and among people, consisting of the values, meanings and beliefs created in social circumstances. In this sense, the technological tools of videoconferencing and instant messaging enabled the interactions between individuals from different countries to impact upon their beliefs concerning culture in language teaching, which might assist teacher education to overcome static views of culture. In the essentialist view the students, their abilities and attitudes towards learning are characterized by troublesome and/or imaginary stereotypes of their religious, ethnic and national cultures.

This may be an indicator that programs for teacher education, both pre-service and in-service, should carefully consider the possibility of conjugating theory and reflective practice through the use of videoconferencing technologies when dealing with the 
teaching of culture in language education. This would accomplish a more contemporary view of culture as an interpersonal process. By including perspectives that go beyond the simplified explanations and the transmission of facts, technology mediated interactions may help to incorporate a pragmatic structure of intercultural competence to language learning. It could do this by expanding the classroom context, as local activity, to the interactions between communities and nations, bringing about elements that promote the perception of the fragmentation and pluralization of one's cultural identity [18] as well as power relations present in society. Language teacher education in contemporary times have an important role of preparing language teachers to deal with the tension between cultural homogenization and heterogenization referred to by Kumaravadivelu [1] and the 'imposed proximity' brought about by globalization. It seems to us that the very same new technologies that contributed to create an era of fast access to information and somehow an oversimplification of things, might paradoxically assist us by enabling the contact between people in interactions that can lead them to grasp the complexity of human beings and their multiple identities.

\section{ACKNOWLEDGMENT}

This work was supported by a grant from São Paulo Research Foundation (FAPESP), process 2009/15.071-5. I would like to thank the foundation for the support given to the research.

\section{REFERENCES}

[1] B. Kumaravadivelu, "A Lingüística Aplicada na era da Globalização,” in Por uma Lingüística Aplicada Indisciplinar, L. P. Moita Lopes, Ed. São Paulo: Parábola Editorial, 2006, pp. 129-147.

[2] M. L. Vassallo, and J. A. Telles, "Foreign language learning in-tandem: theoretical principles and research perspectives,” The ESPecialist, vol. 27, n. 1, pp. 83-118, 2006.

[3] J. A. Telles, and M. L. Vassallo, "Foreign language learning in-tandem: Teletandem as an alternative proposal in CALLT," The ESPecialist, vol. 27, n. 2, pp. 189-212, 2006.

[4] M. E. D. A. André, Etnografia da prática escolar. 4th ed. Campinas: Papirus, 2000.

[5] R. D. Bogdan, and S. K. Bilken, Qualitative research for education. Boston: Allyn and Bacon, 1982.

[6] F. Erickson, "Qualitative methods in research on teaching," in Handbook of research on teaching, M. C. Wittrock, Ed. $3^{\text {rd }}$ ed. New York: MacMillan, 1986, pp.119161.

[7] D. Silverman, Doing qualitative research. London: Sage, 2001.

[8] J. McDonough, and S. McDonough, Research Methods for English Language Teachers. London: Arnold, 1997.

[9] F. M. Pajares, "Teachers' beliefs and educational research: Cleaning up a messy construct”. Review of Educational Research, vol. 62, n. 3, pp. 307-332, 1992.

[10] A. M. B. Barcelos, "Metodologia de pesquisa das crenças sobre aprendizagem de línguas: estado da arte," Revista Brasileira de Lingüística Aplicada, vol. 1, n. 1, pp. 71-92, 2001.
[11] P. R. Moran, Teaching Culture: Perspectives in practice. Canada: Heinle \& Heinle, 2001.

[12] T. Gimenez, Competência intercultural na língua inglesa. Available $<$ http://www.utp.br/nepri/halu/tesig/cornflakes_com_mant eiga.htm> Accessed in 01/09/2008.

[13] C. Geertz, The interpretation of cultures. New York: Basic Books, 1973.

[14] L. Sercu, "Intercultural Communicative Competence in Foreign Language Education: Integrating Theory and Practice," in New Insights into Foreign Language Learning and Teaching, O. St. John, K. van Esch, and E. Schalkwijk, Eds. Frankfurt: Peter Lang, 2004, pp. 115-130.

[15] M. Celce-Murcia, "Rethinking the Role of Communicative Competence in language teaching," in Intercultural Language Use and Language Learning, E. Alcón Soler and M. P. Safont Jordà, Eds. Netherlands: Springer, 2007, pp. 41-57.

[16] S. L. Thorne, "Pedagogical and Praxiological Lessons from Internet-mediated Intercultural Foreign Language Education Research,” in AAUSC 2005: Internet-mediated Intercultural Foreign Language Education, J. A. Belz, and S. L. Thorne, Eds. Boston: Thomson Heinle, 2006, pp. 229.

[17] S. Borg, Teacher Cognition and Language Education: Research and Practice. New York: Continuum, 2006.

[18] S. Hall, A identidade cultural na pós-modernidade. $11^{\text {th }}$ ed. Rio de Janeiro: DP\&A, 2006.

Ana Cristina B. Salomão was born in São Paulo, Brazil. She received a bachelor's degree in Teaching Languages and Literature (Portuguese and English) in 2006. She received a Master's degree in Linguistic Studies from São Paulo State University (UNESP) in 2008 and is at the moment a researcher of the project "Teletandem Brazil: foreign languages for all" (http://www.teletandembrasil.org) and a PhD candidate at São Paulo State University (UNESP), Post-graduate Program in Linguistic Studies, São José do Rio Preto, São Paulo, Brazil. Her major field of study is language teacher education and technology.

She has taught English and Spanish as a foreign language in different contexts in Brazil, and taken part in a number of congresses in her country and internationally. She received a scholarship from AECI, Spain, in 2002, for an exchange program at University of Leon, where she spent 3 months supervising the language laboratory. She has published the following articles on teletandem learning: "O processo de mediação no teletandem" (The meditation process in teletandem) in "Pesquisas em ensino e aprendizagem no Teletandem Brasil: línguas estrangeiras para todos” (Campinas: Pontes, 2010), and "A aprendizagem colaborativa in-tandem: Um olhar sobre seus princípios” (Collaborative language learning in-tandem: a review of its principles) in "Teletandem: um contexto virtual, autônomo e colaborativo para a aprendizagem de línguas no século XXI” (Campinas: Pontes, 2009).

Ms. Salomão is a member of the Association of English Language teachers of the state of São Paulo (APLIESP) and of the Brazilian Association of Applied Linguistics (ALAB). She was the editor of the Newsletter Teletandem News from 2006 to 2008. 